\title{
SOCIEDADE DO CANSAÇO
}

HAN, Byung-Chul. Sociedade do cansaço. Tradução de Ênio Paulo Giachini, 2. ed. ampl. Petrópolis, RJ: Vozes, 2017, 128p.

\section{Valéria Lima Bontempo*}

Ler Sociedade do cansaço, um dos últimos livros do filósofo e ensaísta sulcoreano Byung-Chul Han (Seul/1959), é manter a sensação de ter sua identidade traduzida e dissecada em cada uma de suas páginas. E não é apenas o seu ser que vai sendo desvelado em suas análises, mas também o mundo contemporâneo. É inegável que o resultado desse trabalho constitui-se em uma crítica quanto às formas de sociabilidade e suas enfermidades. Radicado na Alemanha, desde a década de 80, onde doutorou-se em filosofia (1994) defendendo uma tese sobre Martin Heiddegger, Byung-Chul Han transformou-se em uma das vozes mais potentes da atualidade.

É a partir de um instigante diálogo com o pensamento de Michel Foucault, Giorgio Agamben, Nietzsche, Hannah Arendt, Walter Benjamim, dentre outros, que ByungChul Han vai tecendo sua visão sobre os indivíduos e suas "doenças" na sociedade atual. O empreendimento do autor é enfocar as consequências de uma sociedade configurada em torno de um excesso, tanto de positividade como de produtividade, o qual caracteriza a chamada "sociedade do desempenho". A expulsão do diferente, Psicopolítica, No enxame, Sociedade da transparência e Sociedade do cansaço estão entre as suas principais obras. Publicada originalmente na Alemanha, em 2010, Sociedade do cansaço é uma obra curta, organizada em sete capítulos, e sua relevância pode ser medida pela densidade de suas palavras. Sua tese é a ideia de que o mundo ocidental vem se tornando uma sociedade do cansaço.

Em "A violência neuronal", título do primeiro capítulo da referida obra, Han faz uma espécie de análise patológica da sociedade, mostrando que ela sofre de uma série de males que variam conforme suas fases históricas. Se o século passado foi marcado por doenças virais e bacteriológicas, o século XXI é caracterizado pela presença de enfermidades neuronais, tais como depressão, transtorno de déficit de atenção com síndrome de hiperatividade (TDAH), transtorno de personalidade limítrofe, síndrome de Burnout (algo

\footnotetext{
* Mestre em filosofia/UFMG; professora de Filosofia na PUC Minas. E-mail: Valerialimabontempo@gmail.com.
} 
como uma queima do eu, devido a um superaquecimento, o qual resulta em um esgotamento), dentre outras.

A questão discutida por Han é que nenhuma dessas doenças típicas da atualidade é decorrente de infecções. Trata-se de doenças provocadas por um excesso de positividade e, por isso mesmo, nenhuma técnica imunológica mostra-se eficaz para combatê-las.

No segundo capítulo - "Além da sociedade disciplinar” -, Byung-Chul Han mostra que a descrição de Michel Foucault sobre o poder é restrita para explicar o controle dos indivíduos. No lugar de prisões, escolas, hospitais, asilos, dentre outras instituições disciplinares “[...] entrou uma outra sociedade de academias de fitness, prédios de escritórios, bancos, aeroportos, shopping centers e laboratórios de genética” (p. 23). O entendimento é que o século XXI tornou-se uma "sociedade do desempenho". Nela os indivíduos não se submetem mais a instituições disciplinares e surgem como "empresários de si mesmos", como "sujeitos de desempenho" e produção. A máxima Yes, we can passa a predominar e é expressa na valorização de iniciativas e projetos. Aqueles que não se enquadram nessa perspectiva passam a ser vistos como depressivos e fracassados. O desejo na sociedade do desempenho é sempre de maximizar a produção. Contudo, o sujeito do desempenho não deixa de lado o dever. Não há uma ruptura nesse aspecto. Nesse caso, a disciplina funciona como um estágio necessário para o sujeito do desempenho aumentar a sua produtividade.

O resultado desse processo é a produção de uma série de adoecimentos psíquicos, os quais surgem dessa "liberdade paradoxal" do indivíduo. Isso porque o sujeito do desempenho não sofre uma coação externa que o força a trabalhar, no entanto, ele mesmo se submete ao trabalho exaustivo. "O sujeito do desempenho está livre da instância externa de domínio que o obriga a trabalhar ou que poderia explorá-lo. É senhor soberano de si mesmo.” (p. 29). O agressor e a vítima são a mesma pessoa. É uma exploração que se desenvolve a partir de um suposto sentimento de liberdade, em que o "explorador é ao mesmo tempo o explorado" (p 30). Enfim, o "sujeito de desempenho se entrega à liberdade coercitiva ou à livre coerção de maximizar o desempenho" (p. 30).

Nesse contexto, a depressão torna-se uma das patologias da passagem da sociedade disciplinar para a sociedade de desempenho. Alain Ehrenberg afirma que o "depressivo não está cheio, no limite, mas está esgotado pelo esforço de ter de ser ele mesmo" (EHRENBERG apud HAN, 2017, p. 26). Para Ehrenberg a depressão é apenas uma expressão patológica do indivíduo, pois ele não consegue ser ele mesmo. Diferentemente dessa interpretação, Han afirma que a produção de depressão também está ligada à “carência de 
vínculos, característica para a crescente fragmentação e atomização do social" (HAN, 2017, p. 27). A própria origem da depressão, do esgotamento não é tão somente a obrigatoriedade de obedecer a si mesmo, mas também a maneira imperativa que o desempenho se impõe na sociedade.

Face ao excesso de positividade e, consequentemente, o aumento de estímulos na sociedade atual, Han enfoca no terceiro capítulo a falta de condições para a contemplação. É curioso que o leitor ao se deparar com o título desse capítulo - "O tédio profundo" - por vezes, pode ser remetido, numa primeira visada, a entender o tédio como mais uma das enfermidades do nosso tempo. Contudo, é bem o contrário. O tédio profundo é exatamente o que permite a contemplação, o surgimento do descanso. Ocorre que no século XXI reivindicase uma técnica mutitastasking (multitarefa), a qual consiste em modelar a atenção e o tempo dos indivíduos em várias direções. A demanda é por uma atenção multifocal e essa técnica não expressa um progresso civilizatório, visto que os próprios animais recorrem a ela para garantir a sua sobrevivência, pois precisam dividir sua atenção em várias atividades.

Ancorando-se em Walter Benjamin, Han reivindica o estabelecimento de uma atenção profunda, contemplativa para o desenvolvimento da cultura. De acordo com Benjamin, o processo criativo depende desse tédio profundo de um "pássaro onírico, que choca o ovo da experiência.” (BENJAMIN apud HAN, 2017, p. 33). Entretanto, o ninho que garante o descanso desse pássaro está desaparecendo na modernidade. Nela não há espaço para o tédio profundo. E com a perda do repouso perde-se também o dom da escuta, perde-se a "capacidade para a atenção profunda, contemplativa, à qual o ego hiperativo não tem acesso" (HAN, 2017, p. 34).

A contemplação é enaltecida por Han, e o quarto capítulo de sua obra enfoca a visão de Hannah Arendt sobre vida activa e vida contemplativa. Buscando priorizar a vida ativa em detrimento da vida contemplativa, Arendt explicita que a sociedade moderna "aniquila toda a possibilidade de agir, degradando o homem a um animal laborans - um animal trabalhador" (HAN, 2017, p 41). Com isso, o indivíduo ficaria fadado ao anonimato. O pensamento também estaria restrito ao cálculo como função cerebral. Assim, a modernidade caminha para uma "passividade mortal". Nela há uma absolutização do trabalho, e as atividades humanas assemelham-se a processos biológicos. Entretanto, Han afirma que a explicação do animal laborans de Arendt é insuficiente no contexto de uma sociedade de desempenho. "O animal laborans pós-moderno não abandona sua individualidade ou o seu ego para entregar-se pelo 
trabalho a um processo de vida anônimo da espécie" (HAN, 2017, p. 43). Na visão de Han o animal laborans não é passivo e muito menos desprovido de ego.

O autor entende que o animal laborans é "hiperativo" e "hiper-neurótico", e a questão principal é saber: - por que as atividades humanas na pós-modernidade desencadeiam uma agitação tão intensa? A perda da fé tanto em Deus, como no além, ou mesmo na própria realidade é vista como um dos fatores explicativos dessa inquietude que caracteriza os indivíduos na atualidade. Face a essa realidade, tudo torna-se transitório e até mesmo as religiões mostram-se obsoletas para lidar com o medo da morte. Han recorre então a Giorgio Agamben, para mostrar que a vida na contemporaneidade é mais desnuda que a vida do próprio Homo Sacer, pois ela é "absolutamente passível de ser morta" (HAN, 2017, p. 45). Literalmente o Homo Sacer significa homem sagrado, ou seja, trata-se de um indivíduo que, tendo praticado um delito, não pode ser julgado como um transgressor ordinário. $\mathrm{O}$ Homo Sacer é alguém que é excluído da sociedade, podendo "ser morto, sem que o autor seja penalizado por isso" (HAN, 2017, p. 45).

De modo análogo ao Homo sacer, o indivíduo está na condição de uma vida desnuda, é alguém que vive em risco, e sua situação é extremamente transitória e frágil. Nessa condição "reagimos com hiperatividade, com a histeria do trabalho e da produção" (p. 46). E para o autor, o pano de fundo que desencadeia toda essa histeria e nervosismo que caracterizam a sociedade atual advém da absolutização da vita activa e da perda da capacidade contemplativa.

O leitor pode então perguntar: - como alcançar uma vida contemplativa? O quinto capítulo versa exatamente sobre essa questão e sua proposta é usar uma Pedagogia do ver. $\mathrm{Na}$ obra Crepúsculo dos ídolos, Nietzsche busca revitalizar a vida contemplativa, estabelecendo três tarefas para o aprendizado de uma "cultura distinta", a saber: aprender a ler; aprender a pensar; aprender a falar e escrever. Aprender a ver é "habituar o olho ao descanso, à paciência, ao deixar-aproximar-se-de-si, isto é, capacitar o olho a uma atenção profunda e contemplativa, a um olhar demorado e lento" (NIETZSCHE apud HAN, 2017, p. 51). Esse seria o caminho para educar o "caráter do espírito." Precisamos aprender a não reagir de forma impulsiva. "Reagir de imediato e seguir a todo e qualquer impulso já seria uma doença, uma decadência, um sintoma de esgotamento.” (HAN, 2017, p. 52). Dizer sim a tudo que acontece é deixar-se guiar pela hiperatividade, e é preciso aprender a dizer não para fazer resistência aos estímulos opressivos. 
No que se refere à "dialética do ser-ativo", Han mostra-se crítico em relação a Hannah Arendt, pois escapa à filósofa o fato de que "a agudização hiperativa da atividade faz com que essa se converta numa hiperpassividade, na qual se dá anuência irresistivelmente a todo e qualquer impulso e estímulo" (p. 52). No entendimento de Han, a ideia de Hannah Arendt de que, quanto mais ativos nos tornamos mais somos livres não é pertinente, visto que novas formas de coerções são criadas quando a realização da atividade é decorrente da hiperatividade. Para ele somente através da negatividade o sujeito pode parar e interromper esse fluxo mecânico de sua atividade. É preciso hesitação para avaliar a realidade. "Hoje, vivemos num mundo muito pobre de interrupções, pobre de entremeios e tempos intermédios." (p. 53).

No sexto capítulo, Byung-Chul Han faz uma análise patológica do conto "Bartleby, o escritor: a história de Wall Street", de Heman Melville para ilustrar a "história do esgotamento". O relato de Merville mostra o trabalho desumano em um escritório hostil e sombrio, onde os indivíduos são degradados a animal laborans. Esse ambiente é marcado pelo mau-humor e melancolia. Nele qualquer traço de "vida" foi apagado. O personagem do escrivão, Bartleby mostra-se petrificado, apático, calado e submisso às regras da instituição. No entanto, há outros personagens, os quais sofrem distúrbios neuróticos. Estes apresentamse totalmente diferentes de Bartleby, uma vez que padecem de uma excitação neurótica e são hiperativos. Na análise de Han, diferentemente desses personagens "agitados", Bartleby, em função de sua inércia, age a partir do paradigma de uma sociedade disciplinar e não de uma sociedade do desempenho.

Ele ainda não desenvolve sintomas daquela depressão que é uma marca característica da sociedade do desempenho pós-moderna. Os sentimentos de insuficiência e de inferioridade ou de angústia frente ao fracasso ainda não fazem parte da economia dos sentimentos de Bartleby. (p. 62).

O ponto é que Bartleby é alguém que ainda não se deparou com a depressão, pois não é movido pela busca de ser ele mesmo. Ele apenas executa atividades monótonas, que não deixam espaço para qualquer iniciativa. O excesso de trabalho não é a sua marca tanto é que no final do conto vem a revelação de que ele era empregado em um setor de cartas não entregues, uma espécie de arquivo morto. De acordo com Han, a interpretação de Agamben sobre Bartleby é equivocada, uma vez que ele desconsidera o aspecto patológico dessa narrativa, além de transformar o escrivão em "uma figura metafísica 
de pura potência" (p. 63). Na perspectiva de Agamben, ao deixar de escrever, o escriturário atinge a forma extrema do nada, algo como uma "folha em branco", a qual expressa um ato criativo, uma espécie de resistência, que incorpora o "ser da pura potência". Han não acredita nessa possibilidade, e seu argumento é que, se Bartleby “fosse uma 'folha em branco', seria porque está esvaziado de toda referência de mundo e de sentido" (p. 64). Em síntese, o escrivão seria na realidade um ser negativo em direção à morte e não representa uma esperança messiânica, como defendeu Agamben.

No último capítulo, Han explora a ideia de cansaço, mostrando que a sociedade do desempenho reverte-se vagarosamente numa sociedade do doping. Com o uso de determinadas substâncias um cientista poderia ter um neuro-enhancement, ou seja, um melhoramento cognitivo, transformando-se numa máquina de desempenho, uma vez que sua produção é maximizada. O contraponto dessa exacerbação do desempenho é o esgotamento e o cansaço excessivo.

Han problematiza a ideia do cansaço recorrendo a Handke, autor de Ensaio sobre o cansaço. De acordo com Handke na sociedade do desempenho o cansaço age de modo a isolar o indivíduo. Handke divide o cansaço em dois tipos. $\mathrm{O}$ primeiro trata-se de um cansaço solitário, calado, cego, que consome a alma do indivíduo e se expressa de forma violenta, pois leva a pessoa a mudez e a incapacidade para ver. Esse cansaço é uma forma violenta porque acaba com "qualquer comunidade, qualquer elemento comum, qualquer proximidade, sim, inclusive a própria linguagem" (HAN, 2017, p, 71). O segundo tipo de cansaço é falaz e reconciliador e revela-se confiante no mundo, sendo capaz de permeá-lo e reestabelecer a dualidade que foi perdida no cansaço solitário.

Esse cansaço reconciliador e eloquente não se expressa em um estado de esgotamento, mas numa "capacidade especial." É um cansaço que inspira e traz uma serenidade, tornando possível formas de convivência que desapareceram devido à "absolutização do ser ativo". Resumindo, Handke vê esse tipo de cansaço profundo de forma positiva no enfrentamento dessa economia da aceleração. Trata-se de um "cansaço translúcido", que possibilita o acesso a uma atenção totalmente distinta, acesso "àquelas formas longas e lentas que escapam à hiperatenção curta e rápida" (p. 74). É um cansaço fundamental que permite a convivência entre as pessoas em uma comunidade. Esse cansaço não é do eu solitário, do esgotamento, mas um "cansaço-nós", o qual revela uma potência negativa. É um cansaço que assegura um intervalo, um momento sem trabalho, um tempo intermediário. Nesse caso, o cansaço pode criar a possibilidade para o surgimento de um 
elemento inspirador para a fundação de uma comunidade já que ele é um "cansaço com o outro," fazendo assim, um contraponto à sociedade ativa.

Para concluir, ressalta-se que a obra Sociedade do cansaço trata do excesso de positividade e de produtividade na sociedade contemporânea e se destina a todos que têm interesse em refletir sobre a sua organização e os seus rumos. Byung-Chul Han faz a façanha de conectar com o pensamento de filósofos clássicos como Nietzsche, Walter Benjamin, Hannah Arendt, Giorgio Agamben, dentre outros, tecendo seus conceitos a partir de ideias arraigadas na tradição filosófica. É nesse contexto que o autor aborda como a alteridade é expulsa do mundo atual e como a ênfase recai tão somente naquilo que é igual e coloca o indivíduo em uma única direção: maximizar seu desempenho chegando a se autoexplorar. E é para entender os efeitos e as doenças que afetam os indivíduos nesse processo que vale a pena conferir a obra Sociedade do cansaço. 